\title{
Prototype Sistem Informasi Eksekutif Dosen di Perguruan Tinggi Swasta ABCD
}

\author{
ELLA WAHYU GUNTARI ${ }^{1}$, ALDI SIDIK PERMANA ${ }^{2}$, FAJRI RAKHMAT UMBARA, S.T., M.T ${ }^{3}$ \\ 1,2,3]urusan Informatika, Fakultas Sains dan Informatika \\ Universitas Jenderal Achmad Yani \\ Jl. Terusan Sudirman, Cimahi \\ Email : ella.guntari11@gmail.com, sidika175@gmail.com, fajri@unjani.ac.id
}

\begin{abstract}
ABSTRAK
Universitas $A B C D$ merupakan salah satu lembaga institusi pendidikan tinggi swasta di Indonesia. Pengelolaan dan peningkatan kualitas di berbagai program studi yang ada menjadi perhatian utama level eksekutif, khususnya tenaga pengajar pendidikan tinggi (dosen). Untuk meningkatkan kualitas tenaga pengajar pendidikan tinggi, maka diperlukan sebuah sistem informasi yang membantu eksekutif untuk dapat mengakses data dosen, sehingga eksekutif dapat mengambil kesimpulan dari data dosen tersebut. Hasil output dari sistem informasi eksekutif tersebut berupa chart atau diagram laporan mengenai data dosen. Metode pengembangan sistem yang digunakan ialah model prototype, tahapan metode prototype diantaranya adalah mendengarkan pelanggan, merancang dan membuat prototype kemudian dilakukan uji coba.
\end{abstract}

\section{Kata kunci; Sistem Informasi Eksekutif; Prototype; Dosen;}

\section{PENDAHULUAN}

Sistem informasi membantu suatu perusahaan atau organisasi dalam mengelola data menjadi informasi yang dibutuhkan, sekaligus membuat proses kegiatan yang terjadi di dalamnya dapat berjalan secara terogranisir. Salah satunya adalah Sistem Informasi Eksekutif (SIE) yang digunakan untuk para eksekutif dalam mengambil keputusan strategis. Ketesediaan akses informasi strategis secara langsung bagi para eksekutif sangat diperlukan dikarenakan para eksekutif memiliki peranan dalam pengambilan keputusan strategis dan taktis di suatu perusahaan atau organisasi. Sistem Informasi Eksekutif (SIE) merupakan sistem informasi yang menyediakan fasilitas yang fleksibel bagi manager dan eksekutif dalam mengakses informasi eksternal dan internal, yang berguna untuk mengidentifikasi masalah atau mengenali peluang[1].

Universitas $A B C D$ sebagai salah satu lembaga institusi pendidikan tinggi swasta di Indonesia yang memiliki 8 fakultas dan 18 program studi. Pengelolaan dan peningkatan kualitas di berbagai program studi yang ada menjadi perhatian utama level eksekutif, khususnya tenaga pengajar pendidikan tinggi (dosen). Peranan dosen sangat penting dalam proses belajar mengajar, dimana dosen berperan sebagai figur pendidik dengan tugas utama menstransformasikan, mengembangkan, dan menyebarluaskan ilmu pengetahuan melalui pendidikan kepada para mahasiswa.

Kebutuhan informasi tentang tenaga pendidik yang dimiliki Universitas $A B C D$ sangat besar dan dibutuhkan oleh para pimpinan institusi dalam merancang berbagai strategi untuk mendukung visi perguruan tinggi. Oleh karena itu dibutuhkan sistem informasi eksekutif yang dapat menyajikan informasi dalam bentuk tabel dan grafik yang memudahkan penyusunan laporan dan rumusan strategis. 
Sistem informasi eksekutif dapat digunakan untuk menunjukkan kondisi dalam sebuah organisisasi, dan hasil tampilan grafik dan tabel pada dashboard dapat digunakan sebagai bahan pertimbangan level eksekutif universitas untuk pengambilan keputusan dan berfungsi untuk mendukung kegiatan evaluasi[2].

Berdasarkan wawancara yang telah dilakukan, untuk membangun sistem informasi eksekutif ini, model proses yang akan digunakan untuk membangun sistem informasi eksekutif ini adalah model proses prototype, penggunaan model tersebut dilakukan karena pengguna tidak dapat menjelaskan mengenai apa saja informasi yang dibutuhkan, sehingga diperlukannya sebuah prototype agar user dapat melihat dan berinteraksi dengan prototype yang dibuat, selanjutnya jika terdapat kesalahan atau kekurangan pada prototype yang dibuat, maka user dapat menjelaskan bagaimana kebutuhan infromasi yang sesuai dengan apa yang diinginkan.

Untuk meningkatkan kualitas tenaga pengajar pendidikan tinggi, maka diperlukan sebuah sistem informasi yang membantu eksekutif untuk dapat mengakses data dosen, sehingga eksekutif dapat mengambil kesimpulan dari data dosen tersebut. Data dosen yang diperlukan untuk level eksekutif diantaranya adalah informasi mengenai status kerja dosen, informasi mengenai tingkat kinerja dosen yang dapat dilihat berdasarkan jumlah sks yang diambil dosen serta jumlah penelitian dan presensi yang telah dilakukan oleh dosen. Oleh karena itu, Universitas $A B C D$ dalam meningkatkan kualitas khususnya dalam tenaga pengajar, maka berdasarkan rencana strategi (RENSTRA) memerlukan sistem informasi yang dapat menangani hal tersebut

\section{METODE}

\section{A. Metode Pengumpulan Data}

Penelitian ini dilakukan secara sistematis, mulai dari perolehan data, analisa kebutuhan sistem, analisa sistem berjalan, dan perancangan sistem, implementasi perangkat lunak, pengujian sistem dan terakhir pelaporan

Metode yang digunakan dalam pengumpulan data yaitu:

1. Wawancara pada humas PUSSISFO Universitas ABCD

2. Studi data dilakukan untuk menganalisa informasi apa saja yang berkaitan dengan sistem informasi eksekutif dosen di Universitas ABCD

3. Observasi dilakukan secara langsung dengan mendatangi Pusat Sistem Informasi Universitas ABCD

\section{B. Metode Pengembangan Sistem}

Penelitian ini menggunakan metode Prototype, Prototype didefinisikan sebagai satu versi dari sebuah sistem potensial yang memberikan ide bagi para pengembang dan calon pengguna, bagaimana sistem akan berfungsi dalam bentuk yang telah selesai [3]. Dasar dari pemikiran ini adalah membuat prototipe secepat mungkin, bahkan dalam waktu semalam, lalu memperoleh umpan balik dari pengguna yang akan memungkinkan prototype tersebut diperbaiki kembali dengan sangat cepat. Semua rancangan diagaram atau model yang dibuat tidak diharuskan telah sempurna dan final dalam pendekatan prototype. Tujuan utama dari penyiapan rancangan adalah sebagai alat bantu dalam memberi gambaran sistem seperti materi dan menu yang perlu dimasukkan dalam prototype yang akan dikembangkan. Setelah rancangan terbentuk, dilanjutkan dengan mulai mengembangkan prototype [3]. 


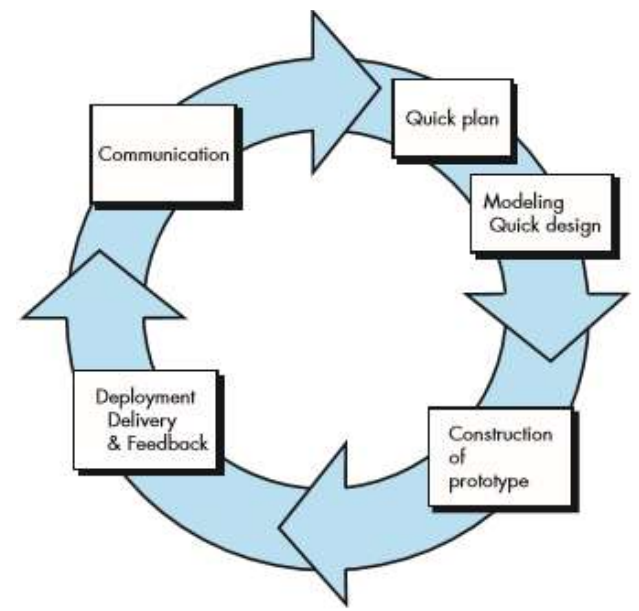

\section{Gambar 1. tahapan dari metode prototipe}

Gambar 1 menjelaskan mengenai tahapan dari metode prototipe, Metode prototype dimulai dari tahap komunikasi. Tim pengembang perangkat lunak melakukan pertemuan dengan para stakeholder untuk menentukan kebutuhan perangkat lunak yang saat itu diketahui dan untuk menggambarkan area-area dimana definisi lebih jauh untuk iterasi selanjutnya[4]. Perencanaan iterasi pembuatan prototipe dilakukan secara cepat. Setelah itu dilakukan pemodelan dalam bentuk "rancangan cepat". Pembuatan rancangan cepat berdasarkan pada representasi aspekaspek perangkat lunak yang akan terlihat oleh para end user (misalnya rancangan antarmuka pengguna atau format tampilan). Rancangan cepat merupakan dasar untuk memulai konstruksi pembuatan prototipe[4]. Prototipe kemudian diserahkan kepada para stakeholder untuk mengevaluasi prototype yang telah dibuat sebelumnya dan memberikan umpan-balik yang akan digunakan untuk memperbaiki spesifikasi kebutuhan. Iterasi terjadi saat pengembang melakukan perbaikan terhadap prototipe tersebut[4].

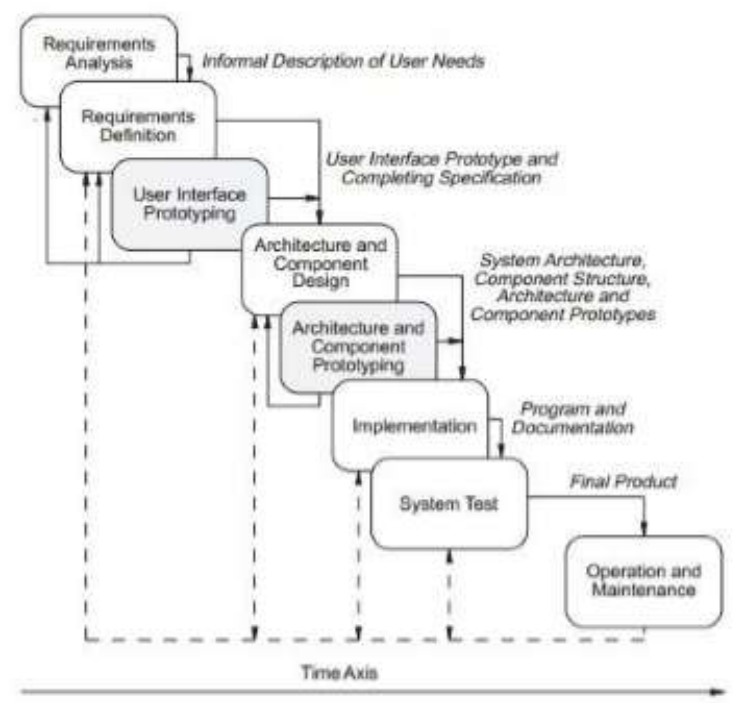

Gambar 2. alur pengembangan sistem

Gambar 2 menjelaskan mengenai alur pengembangan sistem dengan menggunakan metode Prototyping. Pada tahap pertama, dilakukan analisis kebutuhan dan pendefinisian kebutuhan. Kebutuhan yang dimaksudkan disini adalah kebutuhan pelanggan/pengguna. Selanjutnya pada tahap kedua dilakukan pembuatan prototype dari aplikasi yang akan dibangun, mulai dari user interface prototyping dan dilanjutkan hingga penyusunan arsitektur dan komponenkomponen yang berkaitan dengan aplikasi yang akan dibangun. Selanjutnya dilakukan 
pengembangan sistem, dimana aplikasi akan dibangun sesuai dengan prototype yang telah dibuat sebelumnya, dan setelah aplikasi berhasil dibuat sesuai dengan kebutuhan maka dilakukan proses pengujian aplikasi sebelum aplikasi tersebut diimplementasikan[5].

\section{HASIL DAN DISKUSI}

\section{A. Perancangan Sistem}

Perancangan sistem baru dimaksudkan untuk menggambarkan bagaimana sistem yang akan dibagun sebagai betuk penyempurnaan pada sistem yang berjalan. Perancangan ini didapatkan berdasarkan hasil analisis sistem berjalan, analisis pengguna sistem dan analisis data. Perancangan sistem pada bagian ini dilakukan dengan menggunkaan diagram UML.

\section{B. Bisnis Aktor}

Bisnis aktor yaitu berisi penjelasan mengenai aktor-aktor yang terlibat langsung pada sistem yang akan dibagun. Berdasarkan analisis dari pengguna pada sistem yang berjalan terdapat empat aktor yang terlibat yaitu Rektor, Wakil Rektor I, Dekan, dan Ketua Jurusan yang dijelaskan pada Gambar 3.

\section{Activity Diagram}

Activity diagram menggambarkan aliran kerja atau aktivitas dari sebuah sistem. Activity diagram pada Sistem Informasi Eksekutif Dosen di Universitas ABCD dapat dilihat pada Gambar 4.

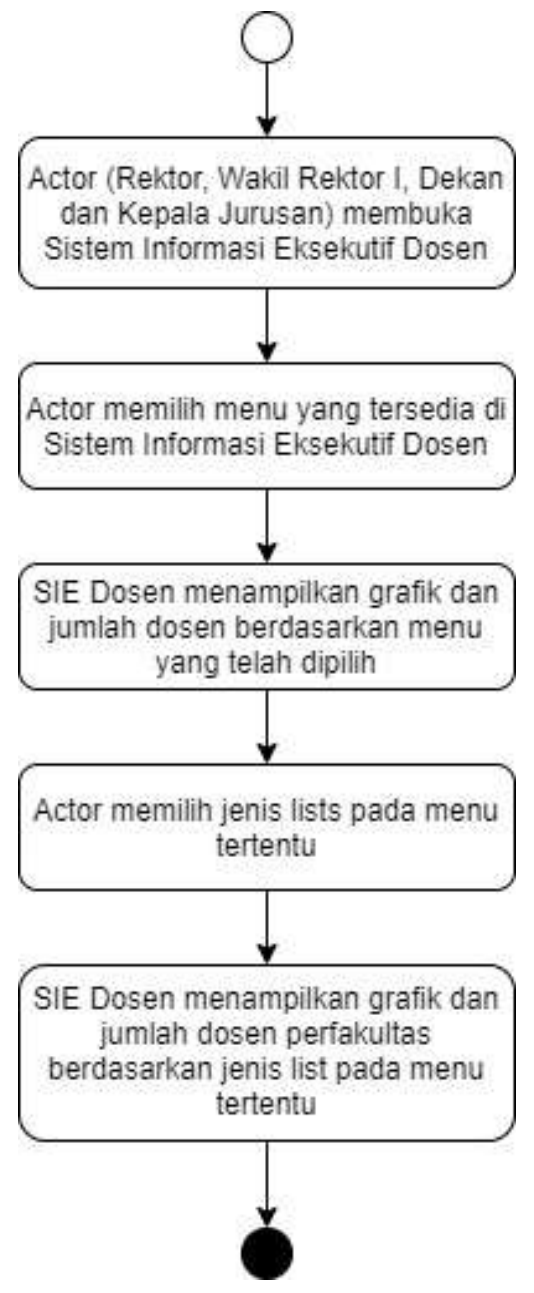

Gambar 3. Activity diagram 


\section{Use Case Diagram}

Use Case Diagram digunakan untuk menyatakan fungsionalitas yang disediakan oleh suatu organisasi secara keseluruhan dan digunakan secara intensif untuk menghimpun konteks sistem[3]. Use Case Diagram Sistem Informasi Eksekutif Dosen di Universitas ABCD dibuat berdasarkan proses bisnis yang telah diidentifikasi. Aktor menggambarkan siapa saja yang berinteraksi secara langsung dengan sistem diantaranya, Rektor, Wakil Rektor I, Dekan, dan Ketua Jurusan. Berikut gambaran Use Case Diagram Sistem Informasi Eksekutif Dosen di Universitas ABCD dapat dilihat pada Gambar 5.

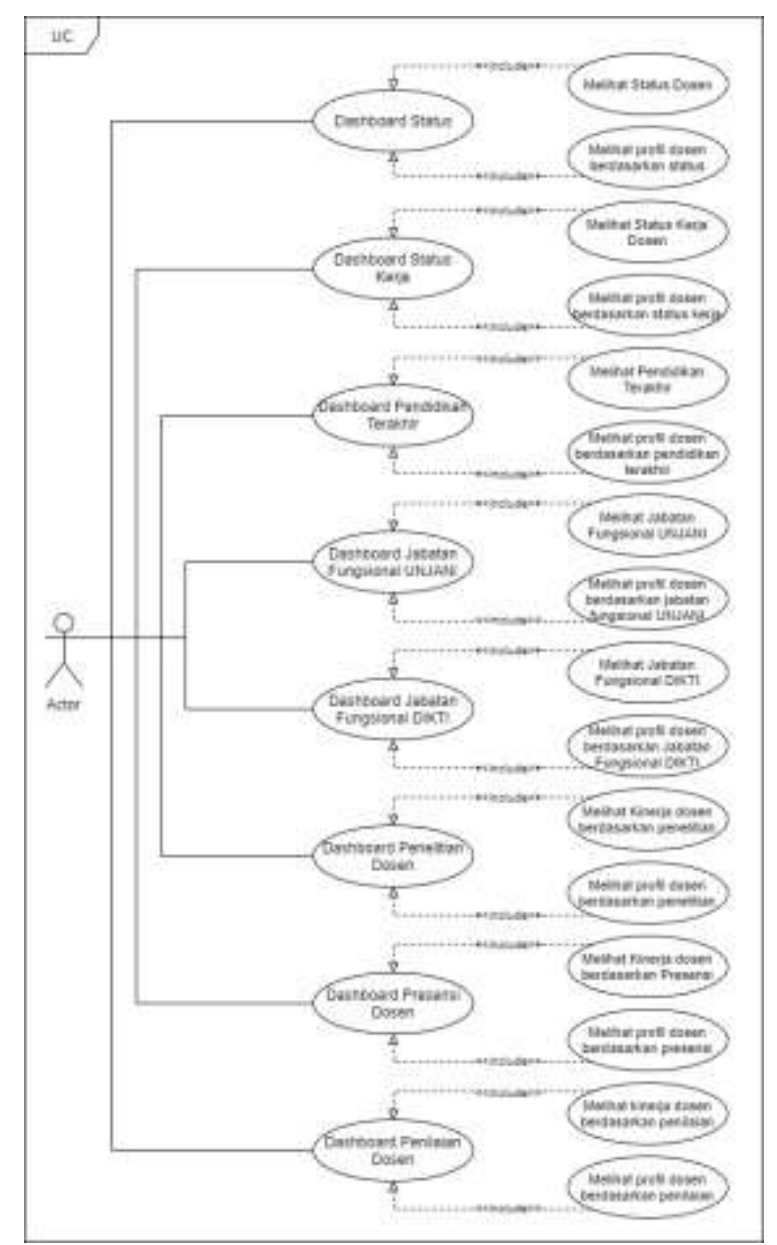

Gambar 4. Use Case Diagram Sistem Informasi Eksekutif Dosen

\section{E. Class Diagram}

Class diagram menggambarkan komponen aplikasi dari perangkat lunak yang akan dibuat. Berikut ini adalah Class diagram sistem informasi eksekutif dosen di Universitas ABCD. 

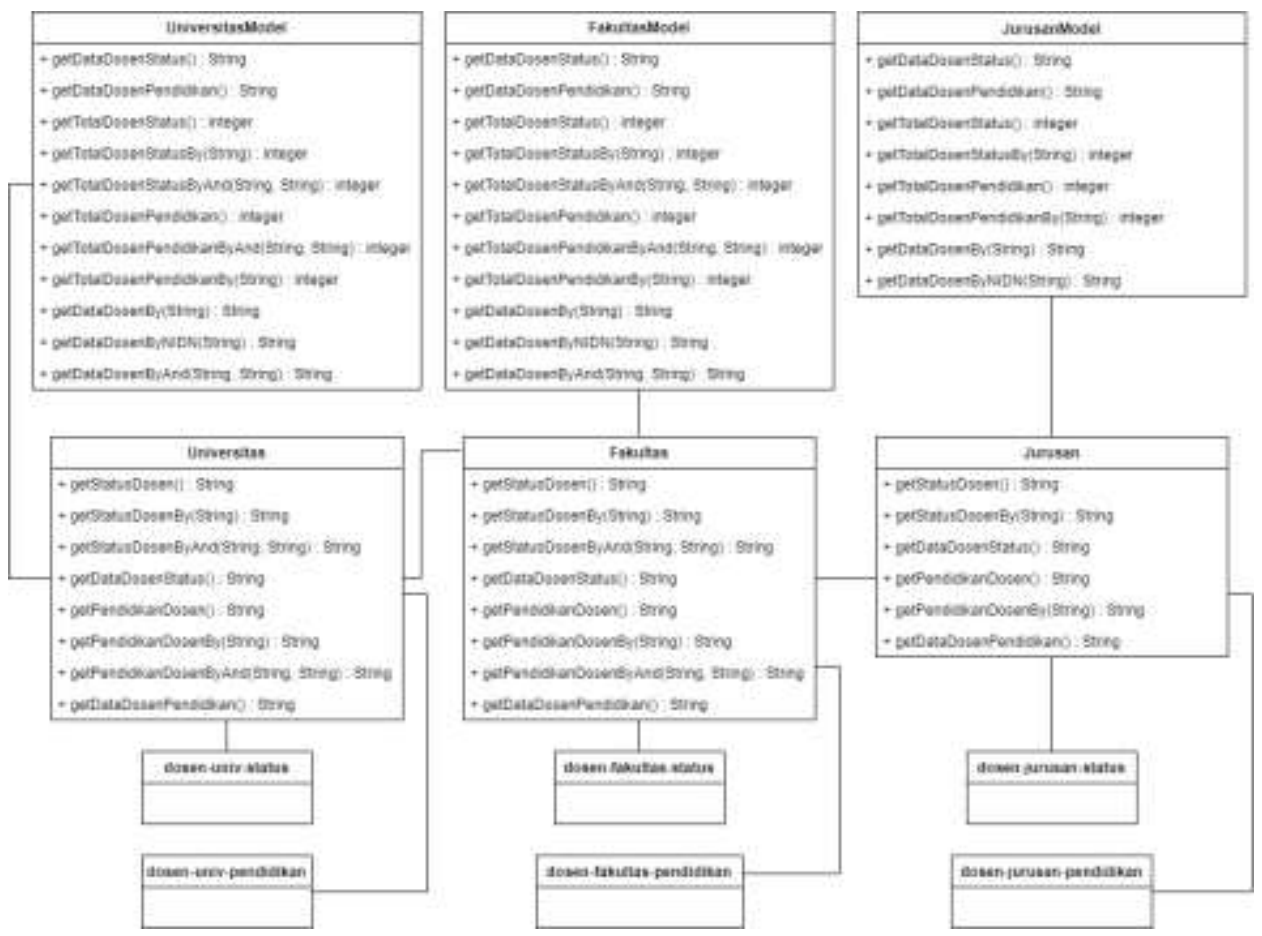

Gambar 5. Class Diagram

\section{F. Desain Antarmuka}

Perancangan antarmuka sistem dalam pembuatan sistem atau aplikasi sangat diharuskan untuk membuat antarmuka sistem karena berfungsi sebagai gambaran yang nantinya akan dijadikan konten yang dilihat oleh pengguna serta untuk menggambarkan fungsi-fungsi atau fitur sistem yang akan dibuat. Di dalam sistem informasi eksekutif dosen terdapat beberapa tampilan dashboard utama dan beberapa sub menu yang diperlukan eksekutif Universitas ABCD, di bawah ini akan digambarkan beberapa tampilan desain utama dari sistem informasi eksekutif dosen di Universitas ABCD.

Tampilan pertama adalah tampilan dari menu status dosen keseluruhan yang ada di Universitas $A B C D$ yang dapat dilihat pada Gambar 6, pada tampilan ini eksekutif dapat melihat jumlah keseluruhan dosen berdasarkan statusnya yang ditampilkan dalam bentuk chart, selain itu terdapat tampilan data dosen yang disajikan dalam bentuk tabel hal tersebut bertujuan supaya eksekutif dapat mengetahui data para dosen.

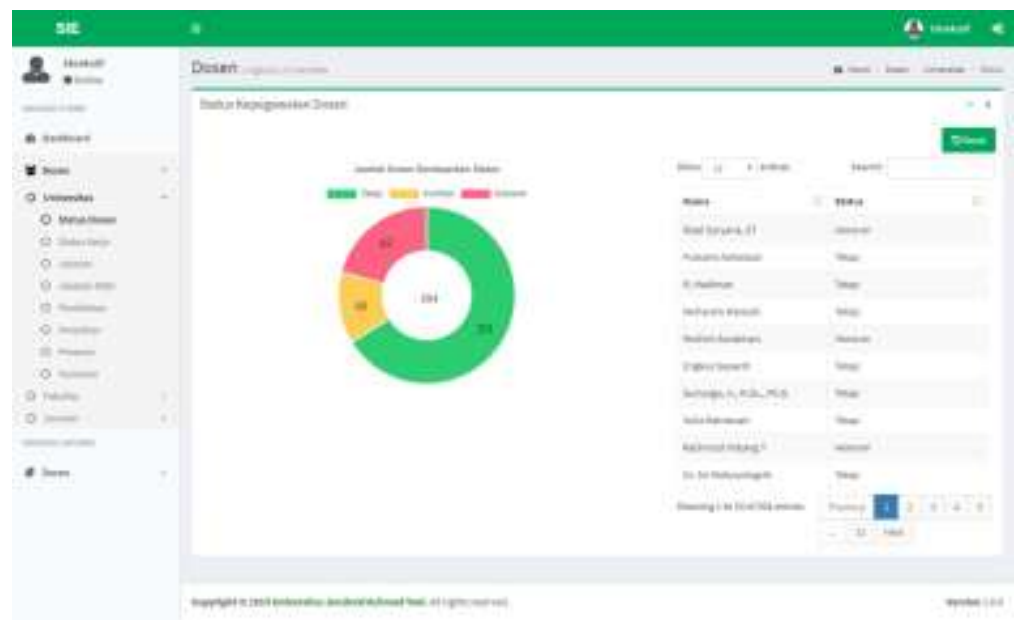

Gambar 6. Tampilan pertama

Paper ini berasal dari Konferensi Nasional SNIA 2019 pada 26 September 
Chart yang dibuat merupakan chart yang interaktif dimana pengguna dapat memilih bagian chart dengan cara klik bagian chart yang ada, kemudian tampilan chart akan berubah sesuai dengan chart yang dipilih (status). Tampilan status dosen dapat di breakdown ketingkatan fakultas, tampilan dashboard status dosen pada tingkat fakultas dapat dilihat pada Gambar 7, pada tampilan ini eksekutif dapat melihat jumlah keseluruhan dosen berdasarkan status di Fakultas Sains dan Informatika yang ada di Universitas $A B C D$, data dosen yang ditampilkan dalam tabel akan menyesuaikan dengan data dosen yang mengajar di fakultas tersebut.

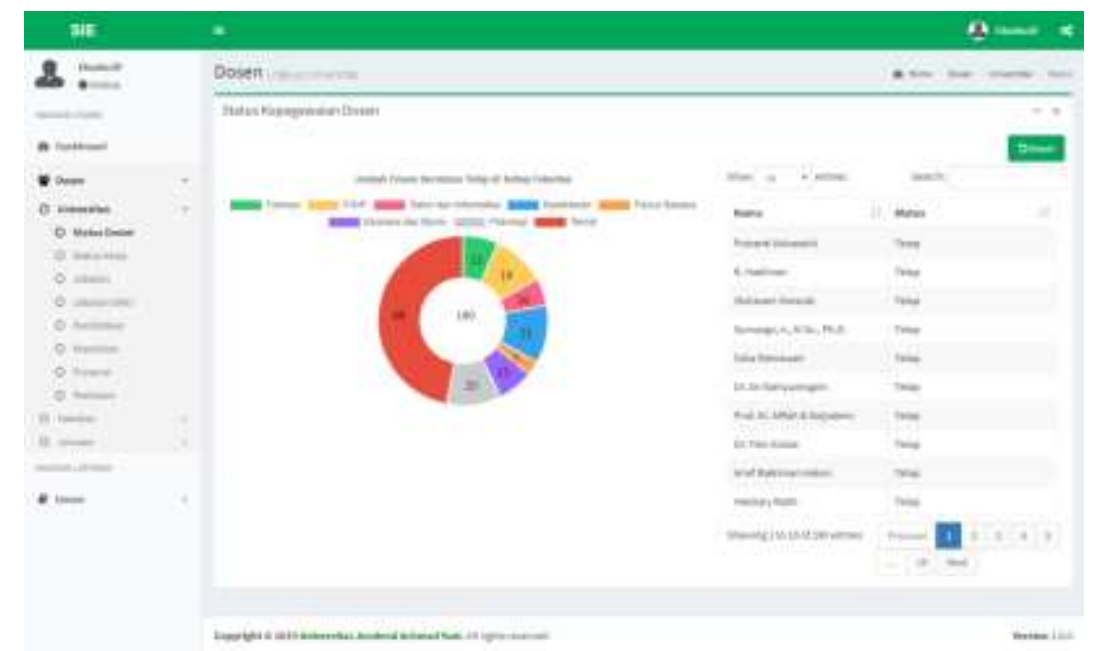

\section{Gambar 7. tampilan dashboard status dosen pada tingkat fakultas}

Tampilan status dosen yang selanjutnya ialah pada tingkat jurusan, tampilan dashboard status dosen pada tingkat jurusan dapat dilihat pada Gambar 8, pada tampilan ini eksekutif dapat melihat jumlah keseluruhan dosen berdasarkan status di Jurusan Informatika yang ada di Universitas $A B C D$, data dosen yang ditampilkan dalam tabel akan menyesuaikan dengan data dosen yang mengajar di jurusan tersebut.

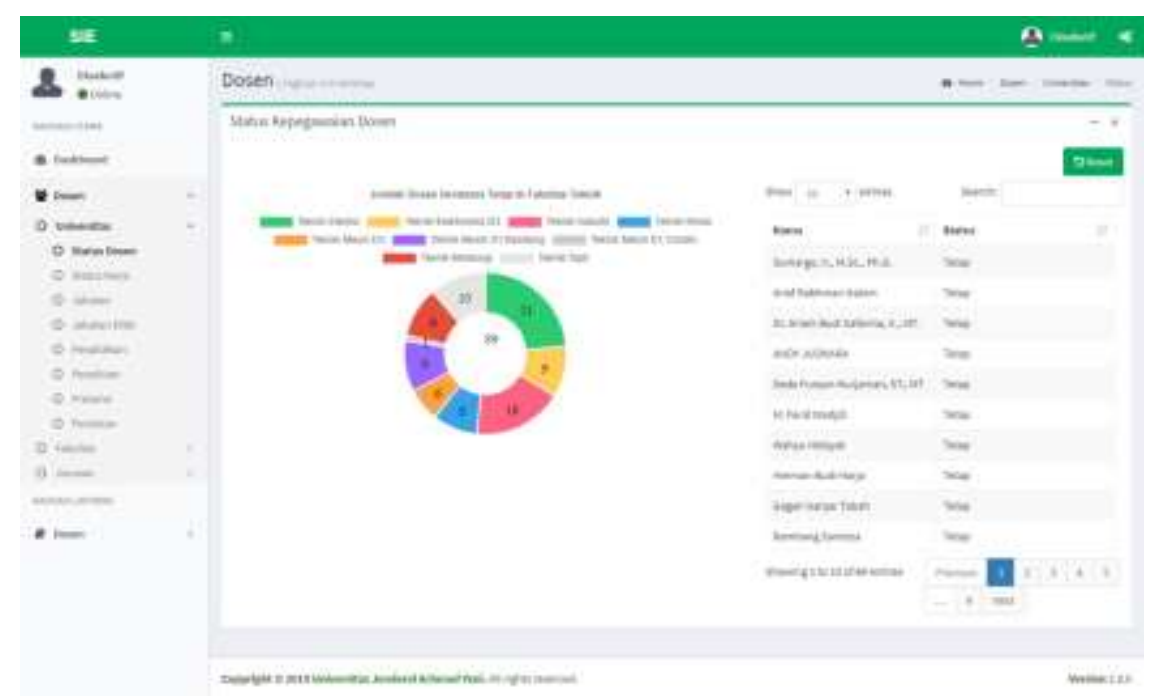

Gambar 8. , tampilan dashboard status dosen pada tingkat jurusan

Selain menampilkan data dosen dalam bentuk tabel, pada halaman dashboard status dosen pada tingkat universitas, fakultas maupun jurusan, eksekutif dapat melihat profil dosen dengan cara memilih dosen berdasarkan NIDN atau Nama dosen yang ditampilkan dalam tabel dosen, kemudian akan terdapat pop-up tampilan profil dosen yang dapat dilihat pada Gambar 9. 


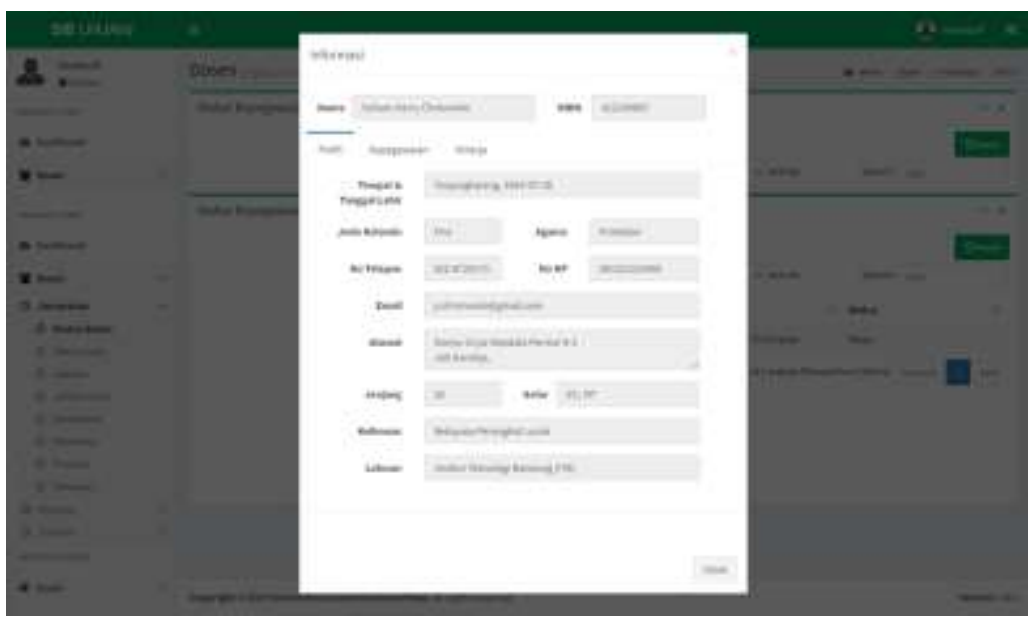

Gambar 9. tampilan profil dosen

Pada pop-up tampilan profil dosen terdapat sub menu yang berisi informasi mengenai status kepegawaian dosen dan kinerja dosen yang bersangkutan, tampilan mengenai status kepegawain dosen dapat dilihat pada Gambar 10.

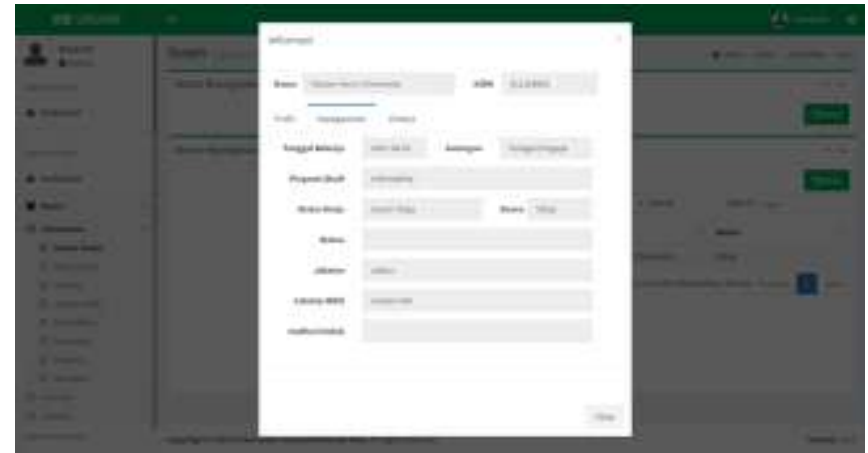

\section{Gambar 10. tampilan mengenai status kepegawain dosen}

Sub menu selanjutnya merupakan kinerja dosen, pada sub menu tersebut akan ditampilkan presentase kinerja dosen selama mengajar di univeristas jenderal achmad yani, presentase kinerja dosen di ukur berdasarkan penelitian yang telah dilakukan, penilaian yang diberikan dosen kepada mahasiswa melalui sistem serta presensi yang dilakukan oleh dosen. Tampilan sub menu kinerja dapat dilihat pada Gambar 11.

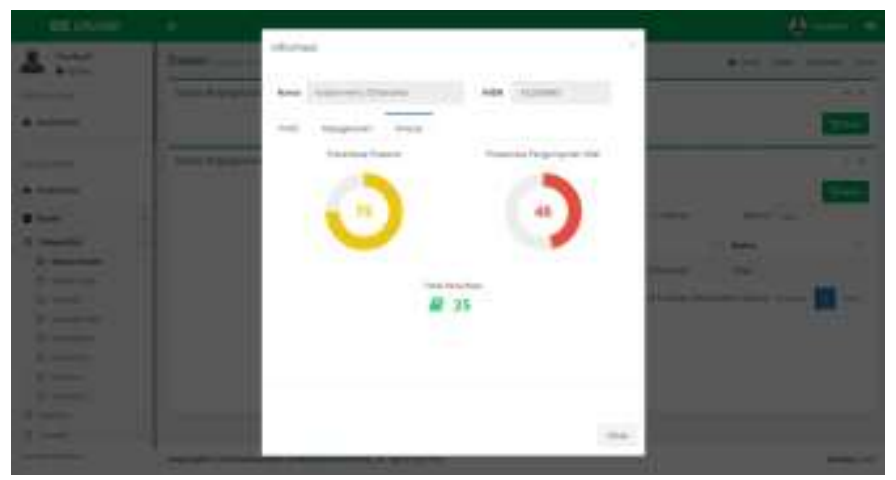

Gambar 11. Tampilan sub menu kinerja

\section{KESIMPULAN}

Setelah melalui tahapan wawancara, analisis sistem yang sedang berjalan, perancangan serta implementasi Sistem Informasi Eksekutif Dosen maka diperoleh kesimpulan sebagai berikut : 
1. Data yang ditampilkan dalam Sistem Informasi Eksekutif merupakan data yang berkaitan dengan dosen, baik dalam bidang akademik maupun kepegawaian

2. Sistem Informasi Eksekutif dosen dapat membantu para eksekutif Universitas ABCD untuk melihat laporan mengenai data dosen dalam bentuk chart atau grafik

3. Sistem ini memudahkan para eksekutif untuk mengambil keputusan strategis mengenai dosen dalam tingkat universitas, fakultas maupun jurusan

4. Keakuratan atau kebenaran jumlah data yang ditampilkan dalam chart atau grafik tergantung dengan data dosen yang tersedia di database sisfo_abcd

\section{UCAPAN TERIMAKASIH}

Penelitian ini dapat dilaksanakan dengan baik berkat bantuan dari berbagai pihak, untuk itu peneliti mengucapkan terima kasih kepada Humas Pusat Sistem Informasi Universitas ABCD yang telah membantu pelaksanaan penelitian ini, sehingga terlaksana dengan baik.

\section{DAFTAR PUSTAKA}

[1] [1] R. A.S, "Sistem Informasi Eksekutif Berbasis Web Pada Fakultas Pertanian Universitas Muhammadiyah Palembang," Student Colloq. Sist. Inf. Tek. Inform., pp. 21-22, 2015.

[2] [2] J. P. Indonesia, "Sistem pendukung informasi eksekutif mobilitas sivitas akademika dan publikasi ilmiah institut pertanian bogor (," vol. 16, no. 2, pp. 1-9, 2013.

[3] [3] A. Firman, H. Wowor, and X. Najoan, "Sistem Informasi Perpustakaan Berbasis Web Application," J. Sist. Inf. Bisnis, vol. 1, no. 2, pp. 66-77, 2016.

[4] [4] Software Engineering Institute, Software Engineering A Practitioner's Approach 7th Edition, 7th ed. 1995.

[5] [5] A. A. Pradipta, Y. A. Prasetyo, and N. Ambarsari, "Pengembangan Web E-Commerce Bojana Sari Menggunakan Metode Prototype," e-Proceeding Eng., vol. 2, no. 1, pp. 10421056, 2015. 